\title{
Roman Tomaszewski
}

(Stupsk)

\section{Słupskie środowisko historyków wychowania}

Pedagodzy lub historycy zajmujący się na Pomorzu Środkowym dziejami edukacji skupiają się wokół Zakładu Historii Oświaty i Wychowania Pomorskiej Akademii Pedagogicznej ${ }^{1}$. Ich obecność można odnotować także w regionalnym oddziale Polskiego Towarzystwa Historycznego, w stowarzyszeniach kaszubskich oraz uczelniach niepaństwowych funkcjonujących na terenach byłych województw - Słupskiego i Koszalińskiego ${ }^{2}$.

Badania historyczno-pedagogiczne $\mathrm{w}$ regionie były prowadzone $\mathrm{z}$ różnym natężeniem i na zróżnicowanym poziomie w latach 1946-1974 bez oparcia o środowisko akademickie $^{3}$. Utworzenie Wyższej Szkoły Pedagogicznej na bazie dawnej Wyższej Szkoły Nauczycielskiej znacznie zwiększyło zaplecze instytucjonalne. Od roku 1978 postacią kluczową dla historyków wychowania był prof. dr hab. Feliks Araszkiewicz, który zintensyfikował badania historyczne (nad oświatą międzywojenną lub w wymiarze regionalnym) swoich pracowników z Zakładu Pedagogiki.

Formalne powstanie Zakładu Historii Oświaty i Wychowania (ZHOiW) w ramach Instytutu Pedagogiki WSP w Słupsku nastąpiło w październiku 1994 r. Tworzył go czteroosobowy zespół kierowany przez dr. Henryka Porożyńskiego, z udziałem prof. dr hab. Stefana Możdżenia, a od 1995 r. także dr. hab. prof. WSP Edmunda Szwedy. Skład osobowy ulegał kilku zmianom w latach 1995-2006. Szczytowo było to dziesięciu pracowników naukowych, w tym trzech samodzielnych na pierwszym, a dwóch na drugim etacie. Liczebność ta była funkcją wielkości zadań dydaktycznych. Obecnie tworzy go sześć osób w tym dwóch samodzielnych pracowników naukowych.

Skład Zakładu w roku akademickim 2006/2007 oraz zainteresowania badawcze ilustruje tabela 1 .

\footnotetext{
${ }^{1}$ Od listopada 2006 Akademii Pomorskiej w Słupsku.

${ }^{2}$ Obszar ten odpowiada pojęciu Pomorza Środkowego.

${ }^{3}$ Były to badania tha polityczno-historycznego uzasadniającego eksperyment słowiński (Kluki) lub wydzielenie tzw. kultury jamneńskiej.
} 
Tabela 1. Pracownicy Zakładu Historii Oświaty i Wychowania

Akademii Pomorskiej w Słupsku (2006-2007 r.)

\begin{tabular}{|c|c|c|c|}
\hline Lp. & Imię i nazwisko & $\begin{array}{c}\text { Stopień - tytuł } \\
\text { stanowisko }\end{array}$ & \multicolumn{1}{c|}{$\begin{array}{c}\text { Zainteresowania } \\
\text { naukowo-badawcze }\end{array}$} \\
\hline 1 & Elżbieta GORLOFF & mgr, asystent & $\begin{array}{l}\text { - najnowsze dzieje szkolnictwa na Pomo- } \\
\text { rzu (okres 1945-1989) } \\
\text { - systemy szkolne w krajach europejskich }\end{array}$ \\
\hline 2 & Henryk POROŻYŃSKI & dr, starszy wykładowca & $\begin{array}{l}\text { - szkolnictwo II Rzeczypospolitej - ten- } \\
\text { dencje integracyjne europejskich syste- } \\
\text { mów oświatowych }\end{array}$ \\
\hline 3 & Tomasz SKONECZNY & dr, adiunkt & $\begin{array}{l}\text { - podstawy społeczne i oświata na wsi } \\
\text { pomorskiej (okres PRL) }\end{array}$ \\
\hline 4 & Izabela STELMASIAK & mgr, asystent & $\begin{array}{l}\text { - strategie wychowania i ich reprezentan- } \\
\text { ci w II Rzzeczypospolitej }\end{array}$ \\
\hline 5 & Roman TOMASZEWSKI & dr hab., prof. nadzw. AP & $\begin{array}{l}\text { - kistoria szkolnictwa resortowego i jego } \\
\text { związki z systemem edukacji narodowej; } \\
\text { - polsko-niemieckie relacje i kontakty } \\
\text { edukacyjne XVIII-XX w. }\end{array}$ \\
\hline 6 & Adam WIRSKI & dr hab., prof. nadzw AP & $\begin{array}{l}\text { - średniowieczne ideały wychowania } \\
\text { - polska oświata na Pomorzu po 1945 r. }\end{array}$ \\
\hline
\end{tabular}

Źródło: Dokumentacja ZHOiW w Instytucie Pedagogiki AP

Obok pracowników Zakładu środowisko historyków wychowania współtworzą osoby współpracujące. Są to pracownicy innych jednostek akademickich: prof. Jerzy Hauziński, prof. Bogdan Zalewski, dr Danuta Apanel, dr Józef Sługocki; lub uczestnicy niektórych programów badawczych: dr Stanisław Kozdrowski, dr Zdzisław Stankiewicz; lub doktoranci mgr Tomasz Butkiewicz (Kilonia - RFN), mgr Marlena Marsico (Rende - Włochy), mgr Anna Ćwiklińska (WSP - Szczytno), mgr Tomasz Cymek (WSNJO - Łódź, AON Warszawa)

Problematyka dziejów szkolnictwa lub szerzej rozumianych instytucji edukacyjnych na Pomorzu jest obecna ( lub była ) w badaniach profesorów Instytutu Historii AP, którzy nie współpracują bezpośrednio lub osobiście z zakładem (np.: Zygmunta Szultki, czy Józefa Lindmajera). Kierunki lub programy badawcze realizowane w słupskim środowisku historyków wychowania zestawione zostały w tabeli 2 .

Tabela 2. Kierunki lub programy badań podejmowane w Zakładzie Historii Oświaty i Wychowania

\begin{tabular}{|c|c|c|c|}
\hline Lp. & Program badań & Uczestnicy programu & $\begin{array}{c}\text { Planowana forma publikacji } \\
\text { lub prezentacji wyników } \\
\text { badań }\end{array}$ \\
\hline & Edukacja w II Rzeczypospolitej & H. Porożyński & J. Stugocki \\
(instytucje, osoby, strategie) & $\begin{array}{c}\text { I. Stelmasiak } \\
\text { Z. Stankiewicz }\end{array}$ & $\begin{array}{l}\text { - rozprawy habilitacyjne } \\
\text { - rozprawy doktorskie }\end{array}$ \\
\hline
\end{tabular}


cd. tab. 2

\begin{tabular}{|c|c|c|c|}
\hline Lp. & Program badań & Uczestnicy programu & $\begin{array}{l}\text { Planowana forma publikacji } \\
\text { lub prezentacji wyników } \\
\text { badań }\end{array}$ \\
\hline 2 & Pedagogie totalitarne (1922-1989) & $\begin{array}{l}\text { R. Tomaszewski } \\
\text { T. Butkiewicz } \\
\text { M. Marsico }\end{array}$ & $\begin{array}{l}\text { - monografia } \\
\text { - rozprawy doktorskie }\end{array}$ \\
\hline 3 & $\begin{array}{l}\text { Wychowanie w najnowszych } \\
\text { dziejach Polski (PRL) }\end{array}$ & $\begin{array}{l}\text { A. Wirski } \\
\text { D. Apanel } \\
\text { E. Gorloff }\end{array}$ & $\begin{array}{l}\text { - monografia } \\
\text { - rozprawa habilitacyjna } \\
\text { - rozprawa doktorska }\end{array}$ \\
\hline 4 & $\begin{array}{l}\text { Szkolnictwo resortowe a system } \\
\text { edukacji narodowej (perspektywa } \\
\text { historyczna) }\end{array}$ & $\begin{array}{l}\text { R. Tomaszewski } \\
\text { T. Cymek } \\
\text { A. Ćwiklińska } \\
\text { S. Kozdrowski }\end{array}$ & $\begin{array}{l}\text { - monografia } \\
\text { - rozprawy doktorskie }\end{array}$ \\
\hline 5 & $\begin{array}{c}\text { Badania regionalne w historii } \\
\text { wychowania (problematyka } \\
\text { pomorska) }\end{array}$ & $\begin{array}{c}\text { Wszyscy etatowi pracownicy } \\
\text { Zakładu }\end{array}$ & - monografia 2007 r. \\
\hline
\end{tabular}

Źródło: Dokumentacja ZHOiW w IP AP

Podstawowe problemy lub bariery rozwojowe Zakładu, a w pewnym stopniu także środowiska historyków wychowania wynikają z formalnych ograniczeń przepływu kadr między dyscyplinami historia - pedagogika ${ }^{4}$. Struktura uczelni i uprawnienia wydziałów w zakresie promowania kadr naukowych są równie istotną barierą. Do roku 2006 poważnym obciążeniem dla pracowników etatowych ZHOiW była wielkość zadań dydaktycznych. Czynnik ten osłabł już i umożliwiło to zwiększenie wysiłku badawczego. Dylemat autokreacji słupskie środowisko historyków wychowania zamierza częściowo rozwiązać przez publikację w 2007 r. monografii współautorstwa pracowników lub współpracowników Zakładu. Na wiosnę 2008 r. planowana jest międzynarodowa konferencja naukowa, którą słupscy historycy wychowania chcą poświęcić tematyce badań regionalnych w historii edukacji.

Istotną dla środowiska kwestią pozostaje przeniesienie naukowych kontaktów międzynarodowych Zakładu z poziomu indywidualnych, personalnych do wymiaru instytucjonalnego wraz ze współdziałaniem w programach badawczych przedstawicieli uczelni zagranicznych.

\footnotetext{
${ }^{4}$ W pełni zasadny jest pogląd prof. S. Sztobryna o nieuprawnionych przemieszczeniach kadr naukowych do historii wychowania np.: z informatyki czy fizyki ( idem, Znaczenie refleksji historycznej w pedagogice, Edukacja i jej historiografia. W poszukiwaniu plaszczyzny twórczego dialogu, red nauk. S. Sztobryn, J. Semkow, Kraków 2006, s.81). Nie można jednak zgodzić się z opinią, że historyk nie jest w stanie z korzyścią dla pedagogiki uprawiać historii (!) wychowania - a pedagog nie jest w stanie opanować warsztatu historyka. Nawet, gdyby ów pogląd został zapisany w regulacji ustawowej (por.: Historia jako synonim antywiedzy, Edukacja i jej historiografia..., s.197-199; 205-206.).
} 